\title{
[5्vPSCR
}

\section{Identification Of Potentialantibiotics - Drugs interaction On Pneumonia Prescription}

\section{Identifikasi Potensi Interaksi Obat-Antibiotikpada Peresepan Pneumonia}

\author{
Yeni Farida $^{1 *}$ dan Anisa Dewi Soleqah ${ }^{1}$ \\ 1 Jurusan Farmasi Fakultas Matematika dan Ilmu Pengetahuan Alam Universitas Sebelas Maret \\ Surakarta \\ *email korespondensi: yenifarida.apt@gmail.com
}

\begin{abstract}
Pneumonia is lower respiratory tract infections, which is the leading cause of death in developing countries. Antibiotics are the primary therapy in cases of pneumonia due to bacteria. The use of antibiotics with other drugs allowing harmful effect. This study aimed to determine the significancy of antibiotics interaction and determine the phase of potential drug interaction could be happened.
\end{abstract}

Data were collected retrospectively by taking data on the patient's medical record. Samples were obtained by purposive sampling. Inclusion criteria were patients diagnosed pneumonia with comorbid and got antibiotic therapy.

The results showed that there were 12 types of drugs combinationthat could potentially cause drug interactions .Potential interactions with other drugs antibiotics based on the literature occurred in the absorption phase (12.82\%), metabolism (35.9\%), and excretion $(51.28 \%)$.

Keywords: drug Interaction, antibiotics, and pneumonia.

Intisari: Pneumonia merupakan penyakit infeksi saluran pernafasan bawah penyebab kematian terbesar terutama di negara berkembang. Antibiotik adalah terapi utama pada kasus pneumonia karena bakteripenggunaanantibiotik bersama dengan obat lain memungkinkan terjadi interaksi yang bersifat merugikan. Penelitian ini bertujuan untuk mengetahuiantibiotik yang memiliki potensi interaksi obat dengan obat lain, dan mengetahui fase terjadinya potensi interaksi obat. Penelitian yang dilakukan merupakan penelitian deskriptif non eksperimental. Pengambilan data dilakukan secara retrospektif dengan mengambil data pada rekam medis pasien dan resep di instalasi farmasi. Sampel diperoleh dengan menggunakan metode purposive sampling dengan kriteria inklusi pasien yang didiagnosa menderita pneumonia dengan penyakit penyerta dan mendapatkan terapi antibiotik. Hasil penelitian menunjukkan bahwa terdapat 12 kombinasi obat yang diidentifikasi berpotensi menyebabkan 
interaksi obat. Potensi interaksi antibiotik dengan obat lain berdasarkan literatur terjadi pada fase absorbsi $(12,82 \%)$, metabolisme $(35,9 \%)$, dan ekskresi $(51,28 \%)$.

Kata kunci: Interaksi obat, antibiotik, dan pneumonia.

\section{Pendahuluan}

Pneumonia adalah peradangan akut pada parenkim paru, bronkiolus respiratorius dan alveoli, menimbulkan konsolidasi jaringan paru sehingga dapat mengganggu pertukaran oksigen dan karbon dioksida di paru-paru. Pneumonia dapat terjadi sepanjang tahun pada semua usia. Manifestasi klinik yang berat dapat terjadi pada usia sangat muda, manula dan pasien dengan kondisi kritis (Dahlan, 2007).

Pneumonia merupakan salah satu penyakit infeksi saluran pernafasan bawah yang merupakan penyebab kematian terbesar terutama di negara berkembang(Misnadiarly, 2008). Berdasarkan hasil Riset Kesehatan Dasar (Riskesdas) tahun 2013, menunjukkan prevalensi nasional Infeksi Saluran Pernapasan Akut (ISPA) di Indonesia yaitu sebesar 25\%, prevalensi pneumonia di Indonesia sebesar 4,5\% dan di Jawa Tengah 5\%.

Pengobatan pneumonia terdiri atas antibiotik dan pengobatan suportif. Antibiotik merupakan terapi utama dalam kasus pneumonia karena bakteri. Beberapa antibiotik makrolida dan kuinolon memiliki sifat sebagai inhibitor enzim, makrolida memberikan efek pada sitokrom P450 isoenzim CYP3A4, sedangkan kuinolon menghambat CYP1A2 (Baxter, 2008). Sifat inhibitor enzim dari beberapa antibiotik makrolida dan kuinolon akan berpotensi menyebabkan interaksi obat pada fase metabolisme.( Lacy et.al, 2010)

Antibiotik yang disarankan sebagai terapi empirik pneumonia rawat inap antara lain sefalosporin generasi 3 dikombinasikan dengan makrolida, floroquinolon monoterapi dan tigesiklin untuk pasien yang intoleran sefalosopin dan floroquinolon (File et.al, 2016). Pemberian antibiotik secara bersamaan dengan antibiotik lain, obat lain atau makanan dapat menimbulkan interaksi obat sehingga memiliki efek yang tidak diharapkan. Efek dari interaksi yang dapat terjadi cukup beragam mulai dari yang ringan seperti penurunan absorpsi obat atau penundaan absorpsi hingga meningkatkan efek toksik obat lainnya (Depkes, 2011).Antibiotik golongan sefalosporin yaitu ceftriaxon berinteraksi dengan furosemid yang berdampak pada peningkatan efek nefro-toksik sefalosporin (Prasetya, 2011). Antasida juga dapat berinteraksi dengan antibiotik fluorokuinolon, sehinggaabsorpsi fluorokuinolon yang diberikan secara oral akan berkurang(Husain et al., 2006).

Berdasarkan uraian di atasefek yang tidak diharapkan dari interaksi akan berpengaruh pada kondisi klinis dari pasien sehingga penting untuk melakukan penelitian tentang identifikasi interaksi antibiotik dengan obat lain pada pasien pneumonia berdasarkan literatur. 


\section{Metode Penelitian}

Penelitian yang dilakukan merupakan penelitian deskriptif non eksperimental. Pengambilan data dilakukan secara retrospektif dengan mengambil data pada rekam medis pasien dan resep di instalasi farmasi.

\subsection{Subyek Penelitian}

Populasi penelitian adalah semua pasien yang terdiagnosis pneumonia menjalani rawat inap di RSUD Dr. Moewardi Surakarta periode 2014-2015. Sampel diperoleh dengan menggunakan metode purposive sampling dengan kriteria inklusi pasien yang didiagnosa menderita pneumonia dengan penyakit penyerta dan mendapatkan terapi antibiotik.

\subsection{Alat dan Bahan}

Bahan yang digunakan dalam penelitian adalah rekam medik pasien rawat inapdan resep dari Instalasi Farmasi di RSUD Dr. Moewardi Surakarta periode 2014-2015 dengan diagnosis utama pneumonia yang memenuhi kriteria inklusi.

Alat yang digunakan dalam penelitian adalah standar pengobatan Stockley's Drug Interaction, Drug Interaction Facts, Medscape, jurnal yang sesuaidengan penelitian serta lembar pengumpulan data.

\subsection{Tempat dan Waktu}

Penelitian ini dilakukan di Instalasi Rekam Medik dan Instalasi RSUD Dr. Moewardi Surakartapada Januari-April tahun 2016

\subsection{Analisa Data}

Data yang diperoleh kemudian diolah dan dianalisis secara deskriptif dengan menghitung persentase pasien berdasarkan distribusi jenis kelamin, penyakit penyerta, rata-rata penggunaan obat, dan penggunaan obat berdasarkan efek farmakologi. Data yang diperoleh juga diidentifikasi potensi interaksi obat yang terjadi berdasarkan literatur.

\section{Hasil dan Pembahasan}

\subsection{Distribusi pasien berdasarkan jenis kelamin}

Dari penelitian yang dilakukan diperoleh 64 pasien yang memenuhi kriteria inklusi. Distribusi pasien berdasarkan jenis kelamin dapat dilihat pada tabel I. 
Tabel I. Distribusi pasien berdasarkan jenis kelamin

\begin{tabular}{cccc}
\hline No & Jenis Kelamin & Jumlah Pasien & Persentase (\%) \\
\hline 1 & Laki-laki & 35 & $54,69 \%$ \\
2 & Perempuan & 29 & $45,31 \%$ \\
& Jumlah & 64 & $100 \%$ \\
\hline
\end{tabular}

Tabel I menunjukkan bahwapasien pneumonia didominasi oleh pasien laki-laki yakni 35 pasien laki-laki (54,69 \%) dan 29 pasien perempuan (45,31\%). Dari penelitian Sajinadiyas (2010) menyatakan bahwa kematian akibat pneumonia berhubungan dengan rokok sebesar $26 \%$ pada penderita laki-laki dan $17 \%$ pada wanita. Paparan asap rokok yang dialami terus menerus pada orang dewasa yang sehat dapat menambah resiko terkena penyakit paru-paru serta menjadi penyebab penyakit bronkitis, dan pneumonia (Elfidasari et al., 2013).

\subsection{Distribusi pasien berdasarkan usia}

Distribusi pasien pneumonia rawat inap pada tahun 2014-2015 di RSUD dr. Moewardi Surakarta berdasarkan usia dapat dilihat pada Tabel II.

Tabel II. Distribusi pasien berdasarkan usia

\begin{tabular}{lccc}
\hline No & Usia* & Jumlah Pasien & Persentase (\%) \\
\hline 1 & 0-5 tahun (Balita) & 7 & $\mathbf{1 0 , 9 4 \%}$ \\
2 & $\mathbf{6 - 1 1}$ tahun (Kanak-kanak) & 1 & $\mathbf{1 , 5 6 \%}$ \\
3 & $\mathbf{1 2 - 1 6}$ tahun (Remaja awal) & 1 & $\mathbf{1 , 5 6 \%}$ \\
4 & $\mathbf{1 7 - 2 5}$ tahun (Remaja akhir) & $\mathbf{6}$ & $\mathbf{9 , 3 8 \%}$ \\
$\mathbf{5}$ & $\mathbf{2 6 - 3 5}$ tahun (Dewasa awal) & 4 & $\mathbf{6 , 2 5 \%}$ \\
$\mathbf{6}$ & $\mathbf{3 6 - 4 5}$ tahun (Dewasa akhir) & 9 & $\mathbf{1 4 , 0 6 \%}$ \\
7 & $\mathbf{4 6 - 5 5}$ tahun (Lansia awal) & $\mathbf{1 4}$ & $\mathbf{2 1 , 8 8 \%}$ \\
$\mathbf{8}$ & $\mathbf{5 6 - 6 6}$ tahun (Lansia akhir) & $\mathbf{2 2}$ & $\mathbf{3 4 , 3 8 \%}$ \\
& Jumlah & $\mathbf{6 4}$ & $\mathbf{6 4}$ \\
\hline
\end{tabular}

Keterangan: * = Pembagian usia berdasarkan kriteria dari Depkes RI (2009).

Tabel II menunjukkan bahwa jumlah terbanyak pasien pneumonia pada rentan usia 56-66 tahun, yaitu sebanyak 22 pasien $(34,38 \%)$. Pada usia lanjut terjadi perubahan anatomi fisiologi dan penurunan daya tahan tubuh. Perubahan anatomi fisiologi akibat proses penuaan memberi konsekuensi penting terhadap cadangan fungsional paru, kemampuan untuk mengatasi penurunan komplians paru dan peningkatan resistensi saluran napas terhadap infeksi (Rizqi dan Helmia, 2014). 
3.3 Distribusi pasien berdasarkan rata-rata penggunaan obat.

Distribusi pasien berdasarkan rata-rata penggunaan obat dapat dilihat pada tabel III.

Tabel III. Distribusi pasien berdasarkan rata-rata penggunaan obat.

\begin{tabular}{|c|c|c|c|}
\hline No & Rata-rata Penggunaan Obat*(Jenis) & $\begin{array}{c}\text { Jumlah } \\
\text { Pasien }\end{array}$ & $\begin{array}{c}\text { Persentase } \\
(\%)\end{array}$ \\
\hline $\mathbf{1}$ & $1-5$ & 3 & $4,69 \%$ \\
\hline 2 & 6-10 & 34 & $53,13 \%$ \\
\hline 3 & 11-15 & 17 & $26,56 \%$ \\
\hline 4 & $16-20$ & 7 & $10,94 \%$ \\
\hline \multirow[t]{2}{*}{5} & $21-25$ & 3 & $4,69 \%$ \\
\hline & Total & 64 & $100 \%$ \\
\hline
\end{tabular}

Keterangan : * Rata-rata penggunaan obat dihitung berdasarkan obat yang digunakan pasienselama dirawat di Instalasi Rawat Inap RSUD Dr. Moewardi

Tabel III menunjukkan bahwa penggunaan obat yang paling banyak adalah $6-10$ obat $(53,13 \%)$. Meningkatnya kompleksitas obat-obat yang digunakan dalam pengobatan saat ini, dan berkembangnya polifarmasi, memungkinan terjadinya interaksi obat sangat besar (Aslam, 2003).Menurut Mega (2013) kejadian interaksi obat terjadi 6 kali lebih tinggi pada subyek yang menerima lebih dari 5 obat perhari dibandingkan dengan pasien yang menerima obat kurang dari 5 obat perhari.

\subsection{Identifikasi Potensi Interaksi Obat}

Identifikasi potensi interaksi obat dilakukan berdasarkan Stockley's Drug Interaction, Drug Interaction Facts, Medscape, jurnal yang sesuai dapat dilihat pada tabel IV.

Tabel IV. Kombinasi antibiotic dengan obat lain yang berpotensi menyebabkan interaksi obat

\begin{tabular}{|c|c|c|c|c|c|c|}
\hline No & \multicolumn{2}{|c|}{ Interaksi Obat } & $\begin{array}{c}\text { Fase Interaksi } \\
\text { Obat }\end{array}$ & Signifikansi & $\begin{array}{c}\text { Jumlah } \\
\text { Peresepan }\end{array}$ & Persentase \\
\hline 1. & $\begin{array}{l}\text { Azithromycin } \\
\text { Antasida }\end{array}$ & dan & Absorbsi & Moderate & 2 & $5,13 \%$ \\
\hline 2. & $\begin{array}{l}\text { Ciprofloxacin } \\
\text { Warfarin }\end{array}$ & dan & Metabolisme & Moderate & 2 & $5,13 \%$ \\
\hline 3. & $\begin{array}{l}\text { Ciprofloxacin } \\
\text { Propanolol }\end{array}$ & dan & Metabolisme & Moderate & 1 & $2,56 \%$ \\
\hline 4. & $\begin{array}{l}\text { Cotrimoksazol } \\
\text { Rifampisin }\end{array}$ & dan & Metabolisme & Minor & 1 & $2,56 \%$ \\
\hline 5. & $\begin{array}{l}\text { Ceftriaxon } \\
\text { Furosemid }\end{array}$ & dan & Ekskresi & Moderate & 20 & $51,28 \%$ \\
\hline 6. & $\begin{array}{l}\text { Metronidazol } \\
\text { Simvastatin }\end{array}$ & dan & Metabolisme & Mayor & 1 & $2,56 \%$ \\
\hline 7. & $\begin{array}{l}\text { Metronidazol } \\
\text { Methylprednisol }\end{array}$ & $\begin{array}{l}\text { dan } \\
\text { ne }\end{array}$ & Metabolisme & Moderate & 1 & $2,56 \%$ \\
\hline
\end{tabular}




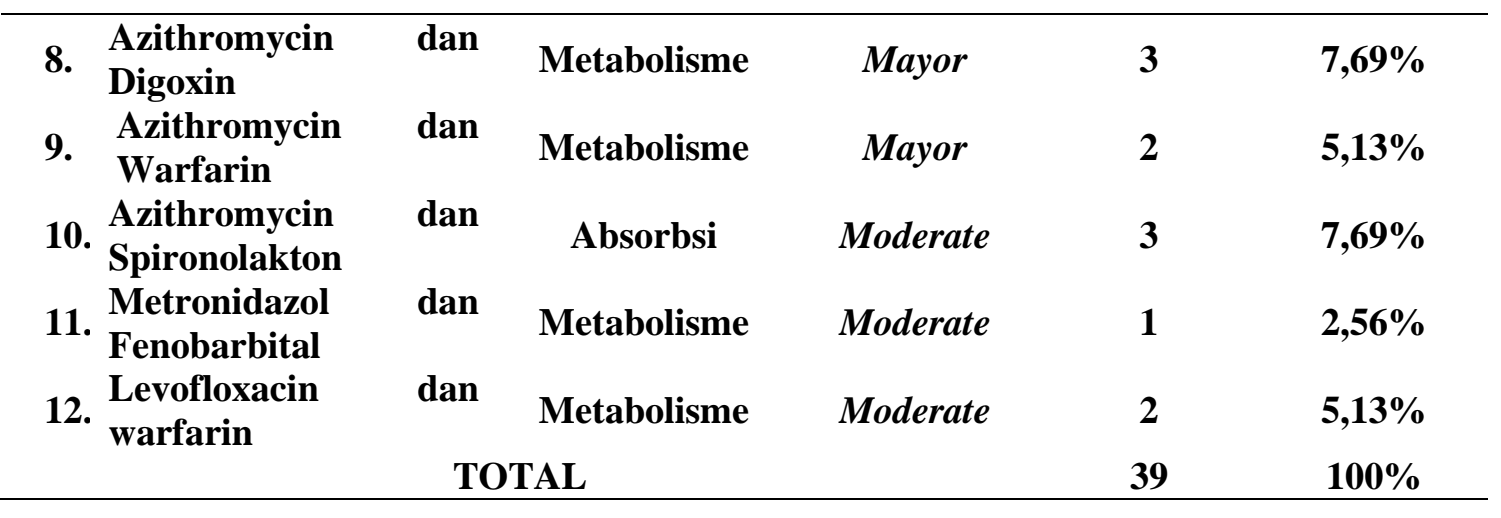

Dari tabel IV dapat dilihat bahwa potensi interaksi obat paling banyak terjadi pada fase ekskresi yaitu 51,28\% dan potensi interaksi obat paling banyak memiliki signifikansi moderate yaitu sebanyak 79,49\% berdasarkan literatur. Dari data di atas berikut ini akan dijelaskan mekanisme interaksi obatnya:

1. Antasida yang digunakan bersama dengan azithromycin dapat mengurangi puncak tingkat azithromycin karena terjadi penurunan penyerapan pada saluran pencernaan (Medscape, 2016). Penggunaan azithromycin dan antasida dalam 10 subyek sehat kadar puncak serum dan penyerapan, azithromycin berkurang oleh antasida.Disarankan pada penggunaan azithromycin seharusnya tidak diberikan pada waktu yang sama dengan antasida, tetapi harus diambil setidaknya 1 jam sebelum atau 2 jam sesudah penggunaan azithromycin (Baxter, 2008).

Penurunan puncak serum dan penyerapan azithromycin akan berpengaruh pada efektivitas terapi dari azithromycin dan dapat dilihat dari kondisi klinis pasien sebelum dan sesudah menerima terapi dari azithromycin. Dari ke dua pasien yang berpotensi memiliki interaksi obat sebelum menerima terapi azithromycin mengeluhkan batuk dan sesak nafas. Setelah pasien menerima terapi azithromycin kondisi klinis pasien membaik dan dapat dikatakan penggunaan antasid tidak berpengaruh terhadap efektivitas terapi azithromycin. Hal ini bisa terjadi jika waktu penggunaan antasida diambil 1 jam sebelum atau 2 jam sesudah penggunaan azithromycin.

2. Ciprofloxacin dan warfarin yang digunakan secara bersamaan memiliki potensi interaksi obat yang menyebabkan perdarahan. Peningkatkan risiko perdarahan ini terjadi karena penghambatan CYP1A2 yang merupakan salah satu enzim utama yang bertanggung jawab untuk metabolisme warfarin( Schelleman et al., 2008).

Penghambatan enzim CYP1A2 oleh ciprofloxacin akan memperlambat biotransformasi warfarin sehingga bioavailibilitas warfarin dalam tubuh akan meningkat. Peningkatan bioavailibilitas warfarin membuat efek warfarin lebih besar dan lebih lama, sehingga meningkatkan risiko perdarahan. Resiko perdarahan dapat dilihat dari data INR(International normalized ratio) pasien, namun data tersebuttidak tertera dalam rekam medik, sehingga tidak dapat diketahui efek perdarahan dari penggunaan warfarin dan ciprofloxacin. Interaksi obat ini memiliki signifikansi moderate, jika terjadi peningkatan INR atau penurunan kondisi klinis pasien disarankan untuk menghentikan terapi kedua obat ini secara bersamaan dan gunakan alternatif obat lain. 
3. Penggunaan ciprofloxacin dan propanolol berpotensi mengakibatkan interaksi obat. Efek farmakologis dari propanolol yang dimetabolisme oleh sitokrom P-450 dapat meningkat. Ciprofloxacin dapat menurunkan klirens propanolol dengan menghambat metabolismenya di hati (Tatro, 2009).

Penghambatan metabolisme propanolol akan meningkatkan ketersediaan propanolol dalam sirkulasi sistemik, sehingga efek dari propanolol lebih besar dan lebih lama.Peningkatan efek farmakologi dari propanolol akan meningkatkan resiko hipotensi, namun dalam data keluar rumah sakit pasien tidak tertera data tekanan darah pasien sehingga tidak dapat diketahui efek interaksi obat terahadap kondisi klinis pasien. Interaksi obat ini memiliki signifikansi moderate, jika terjadi terjadi penurunan tekanan darah secara drastis atau penurunan kondisi klinis pasien disarankan untuk menghentikan terapi kedua obat ini secara bersamaan dan menggunakan alternatif obat lain.

4. Cotrimoxazol dan rifampisin yang digunakan secara bersamaan akan menimbulkan penurunan level cotrimoxazol dan meningkatkan serum rifampisin. Rifampisin memiliki sifat inducer terhadap enzim CYP2C9. Rifampisin akan menurunkan tingkat atau efek dari sulfametoksazol dengan mempengaruhi hati enzim CYP2C9 (Medscape, 2016). Rifampisin yang menginduksi enzim CYP2C9 dapat meningkatkan metabolisme dari cotrimoxazol sehingga menurunkan AUC(Area Under Curve) dari cotrimoxazol yang akan berakibat pada penurunan atau bahkan kegagalan terapi dari cotrimoxazol.

Penurunan khasiat dari cotrimoxazol akan berpengaruh terhadap kondisi klinis pasien setelah menerima terapi cotrimoxazol. Kondisi klinis pasien sebelum menerima terapi cotrimoxazol pasien mengeluhkan batuk berdarah, demam dan sesak nafas, setelah menerima terapi cotrimoxazol kondisi klinis pasien membaik yang ditandai dengan pasien tidak mengeluhkan batuk berdarah, demam dan sesak. Pasien ini tidak hanya menerima terapi antibiotik tunggal, tetapi juga dikombinasikan dengan ceftriaxon sehingga penurunan khasiat cotrimoxazol tidak berpengaruh terhadap kondisi klinis pasien. Namun jika terjadi penurunan kondisi klinis pasien karena penurunan khasiat dari cotrimoxazol dapat dilakukan peningkatan dosis cotrimoxazol sehingga terapi dari cotrimoxazol tercapai.

5. Penggunaan antibiotik ceftriaxon bersama dengan furosemid akan menyebabkan potensi interaksi obat pada fase ekskresi. Furosemid dapat meningkatkan $25 \%$ waktu paruhdari ceftriaxon dan menurunkan klirensnya, sehingga meningkatkan efek nefro-toksiknya (Prasetya, 2011). Peningkatan nefrotoksik ceftriaxon akan mengganggu fungsi ginjal pasien dan penurunan fungsi ginjal dapat dilihat pada kreatinin pasien.

Peningkatan efek nefrotoksik dari ceftriaxon akan mengganggu fungsi ginjal dari pasien, gangguan pada fungsi ginjal dapat dilihat pada hasil pengecekan kreatinin pasien. Namun pada rekam medik pasien tidak terdapat data kreatinin pasien, sehingga tidak diketahui efek nefrotoksisitas dari ceftriaxon terhadap fungsi ginjal pasien. Interaksi obat ini memiliki signifikansi moderate, jika terjadi peningkatan kadar kreatinin dalam darah pasien atau penurunan kondisi klinis pasien disarankan untuk menghentikan terapi kedua obat ini secara bersamaan dan menggunakan alternatif obat lain. 
6. Metronidazol yang dikonsumsi dengan simvastatin akan menimbulkan interaksi obat pada fase metabolisme. Metronidazol akan mempengaruhi enzim di ususatau enzim CYP3A4 hati yang memetabolisme simvastatin sehingga menyebabkan efek simvastatin meningkat (Medscape, 2016). Penggunaan simvastatindengan obat yang menghambat enzim CYP3A4 memperbesar resiko myopati dengan efek meningkatkan kadar plasma terutama pada dosis agak tinggi (di atas $20 \mathrm{mg}$ ) (Tjay dan Rahardja, 2007).

Interaksi obat ini memiliki signifikansi mayor, efek interaksi obat mayor dapat mengancam jiwa pasien atau menyebabkan kerusakan permanen. Terapi kedua obat ini secara bersamaan dihentikan dan digunakan alternatif obat lain untuk mencegah interaksi obat yang tidak diinginkan. Peningkatan efek dari simvastatin akan mempengaruhi kadar kolesterol dalam darah pasien, namun pada data rekam medik tidak tertera data kolesterol pasiensehingga tidak dapat diamati pengaruh efek interaksi obat terhadap kondisi pasien.

7. Methylprednisolone adalah salah satu obat golongan kortikosteroid. Methylprednisolon yang dikonsumsi bersamaan dengan metronidazol akan menyebabkan interaksi obat dalam fase metabolisme. Metronidazol akan meningkatkan efek methylprednisolon dengan menghambat enzim CYP3A4 hati (Medscape, 2016). Penghambatan enzim CYP3A4 oleh metronidazol akan memperlambat proses metabolisme dari methylprednisolon sehingga bioavailibilitas dari methylprednisolon meningkat. Hal tersebut yang membuat efek dari methylprednisolon lebih besar dan lebih lama.

Interaksi obat ini memiliki signifikansi moderate, jika terjadi penurunan kondisi klinis pasien maka dapat dilakukan penyesuaian dosis methylprednisolon dengan menurunkan dosisnya agar dosis yang diberikan sesuai untuk terapi pasien.

8. Azithromycin adalah salah satu jenis antibiotik golongan makrolida. Penggunaan antibiotik ini dengan digoxin akan menimbulkan interaksi obat. Azithromycin akan meningkatkan efek dari digoxin dengan mengubah (menurunkan) flora usus (Medscape, 2016). Salah satu fungsi dari flora usus adalah memetabolisme obat, digoxin merupakan salah satu obat yang dimetabolisme oleh flora usus. Inaktivasi digoxin ditemukan ketika diinkubasi dengan bakteri usus Eggerthella lenta secata in vitro dekade lalu. Namun, mekanisme yang mendasari dari inaktivasi digoxin masih belum jelas (Lu et al, 2014).

Kondisi klinis pasien pada saat keluar rumah sakit pada 2 pasien membaik, namun pada 1 pasien masih dalam kondisi lemah. Perbedaan kondisi klinis pasien ini terjadi mungkin karena perbedaan lama waktu pemberian azithromycin dan digoxin. Pasien yang memiliki kondisi klinis membaik menerima azithromisin dan digoxin secara bersamaan hanya 1 hari, sedangkan pada pasien yang memiliki kondisi klinis lemah menerima azithromisin dan digoxin secara bersamaan selama 3 hari. Interaksi obat ini memiliki signifikansi mayor, efek interaksi obat mayor dapat mengancam jiwa pasien atau menyebabkan kerusakan permanen. Terapi kedua obat ini secara bersamaan dihentikan dan digunakan alternatif obat lain untuk mencegah interaksi obat yang tidak diinginkan.

9. Penggunaan azithromycin dan warfarin secara bersamaan akan mengakibatkan interaksi obat. Interaksi obat ini terjadi pada fase metabolisme, azithromycin menurunkan metabolisme warfarin sehingga efek dari warfarin meningkat (Medscape, 2016). Penurunan 
metabolisme dari warfarin akan meningkatkan bioavailibilitas dari warfarin efek warfarin menjadi lebih besar dan lebih lama. Peningkatan efek warfarin akan menimbulkan resiko terjadinya perdarahan, resiko perdarahan dapat dilihat dari nilai INR.

Interaksi obat ini memiliki signifikansi mayor, efek interaksi obat mayor dapat mengancam jiwa pasien atau menyebabkan kerusakan permanen. Terapi kedua obat ini secara bersamaan dihentikan dan digunakan alternatif obat lain untuk mencegah interaksi obat yang tidak diinginkan.

10. Azithromycin merupakan salah satu jenis antibiotik yang masuk dalam golongan makrolida. Antibiotik ini jika digunakan bersama spironolakton akan menimbulkan interaksi obat pada fase absorbsi. Pada penelitian ini diketahui ada 3 peresepan yang berpotensi memiliki interaksi obat ini. Spironolakton akan meningkatkanefek azithromycin (Medscape, 2016). Azithromycin sebagai substrat dari P-glikoprotein bioavailibilitasnya meningkat karena Pglikoprotein di usus dihambat oleh spironolakton. Obat-obat yang menghambat Pglikoprotein di usus akan meningkatkan bioavailibilitas substrat P-glikoprotein (Gitawati, 2009).Interaksi obat ini memiliki signifikansi moderate sehingga perlu memonitoring kondisi klinis pasien, jika terjadi penurunan kondisi klinis pasien maka perlu dilakukan penyesuaian dosis dari azithromycin

11. Fenobarbital telah diketahui sebagai inducer enzim hati, secara nyata dapat meningkatkan metabolisme dan klirens metronidazol sehingga menyebabkan kegagalan pengobatan metronidazol. Bukti klinis dari seorang wanita dengan trikomoniasis vagina diberi metronidazol selama setahun, tetapi infeksi terjadi lagi tidak lama setelah infeksi itu berhenti. Ketika disadari bahwa ia juga mengambil fenobarbital $100 \mathrm{mg}$ sehari, dosis metronidazol dua kali lipat untuk $500 \mathrm{mg}$ tiga kali sehari, dan dia sembuh setelah 7 hari. Penelitian farmakokinetik menemukan bahwa klirens metronidazol meningkat (waktu paruh 3,5 jam dibandingkan dengan waktu paruh normal 8 sampai 9 jam). (Baxter, 2008).

Peningkatan metabolismedan klirens metronidazol menyebabkan kegagalan terapi. Kegagalan terapi metronidazol akan berpengaruh pada kondisi klinis pasien sebelum dan sesudah menerima terapi, namun kondisi klinis pasien membaik setelah menerima terapi metronidazol. Hal ini dikarenakan pada pasien ini tidak hanya menerima terapi tunggal metronidazol saja tetapi pasien ini menerima terapi kombinasi antibiotik yakni metronidazol dan meropenem. Interaksi kedua obat ini memiliki signifikansi moderate, sehingga perlu memonitoring kondisi klinis pasien dan jika terjadi penurunan kondisi klinis karena penurunan efek dari metronidazol maka dosis metronidazolditingkatkanagar efektivitas terapinya tercapai.

12. Levofloxacin adalah salah satu antibiotik golongan flouroquinolon. Levofloxacin dan warfarin yang digunakan secara bersamaan memiliki potensi interaksi obat yang menyebabkan peningkatan efek warfarin dengan cara menurunkan metabolisme dari warfarin (Medscape, 2016). Warfarin adalah jenis obat antikoagulan yang dimetabolisme oleh enzim CYP1A2. Mekanisme fluoroquinolon dalam meningkatkan risiko perdarahan dengan cara menghambat CYP1A2 yang merupakan salah satu enzim utama yang bertanggung jawab untuk metabolisme warfarin (Schellemanet al., 2008). 
Peningkatan efek warfarin akan menimbulkan resiko terjadinya perdarahan, yangdapat dilihat dari nilai INR. Data rekam medik pasien tidak terdapat data INR sehingga tidak dapat melihat efek dari peningkatan efek dari warfarin. Signifikansi interaksi kedua obat ini adalah moderate. Jika terjadi peningkatan nilai INR atau penurunan kondisi klinis pasien, maka dosis penggunaan warfaindisesuaikandengan menurunkan dosisnya.

\section{Kesimpulan}

Pada peresepan 64 pasien pneumonia dengan penyakit penyerta ditemukan 12 jenis obat yang berpotensi berinteraksi dengan antibiotik.Potensi interaksi antibiotik dengan obat lain berdasarkan literatur terjadi pada fase absorbsi (12,82\%), metabolisme (35,9\%), dan ekskresi $(51,28 \%)$.

\section{Conflicts of Interest}

The authors declare no conflict of interest 


\section{Daftar Pustaka}

Aslam, Moh., Tan, C.K., dan Priyatno, A., 2003, Farmasi Klinis, PT Elex Media Komputindo kelompok Gramedia, Jakarta.

Baxter, K., 2008, Stockley's Drug Interaction Eight edition, Pharmaceutical Press, United States of America.

Balitbang Kemenkes RI, 2013, Riset Kesehatan Dasar; RISKESDAS, Balitbang Kemenkes RI, Jakarta.

Dahlan, Z., 2007, Buku Ajar Ilmu Penyakit Dalam Jilid II Edisi IV, Pusat Penerbitan Departemen Ilmu Penyakit Dalam FKUI, Jakarta.

Depkes RI, 2009, Profil Kesehatan Indonesia, Departemen Kesehatan Republik Indonesia, Jakarta.

Depkes RI, 2011, Peraturan Menteri Kesehatan Republik Indonesia Nomor 2406/Menkes/Per/XII/2011 Tentang Pedoman Umum Penggunaan Antibiotik, Departemen Kesehatan RI, Jakarta.

Elfidasari, D., Noriko, N., Mirasaraswati, A., Feroza, A., dan Canadianti, S.F., Deteksi Bakteri Klebsiella pneumonia pada Beberapa jenis Rokok Konsumsi Masyarakat, Jurnal Al-Azhar Indonesia Seri Sains Dan Teknologi, 2013; 21: 41-47.

File, T.M., Bartlet J.G., Thomer, A.r. Treatment of community-acquired pneumonia in adults who require hospitalization, Up to Date Wolters Kluwer, tersedia di http://www.uptodate.com/contents/treatment-of-community-acquired-pneumonia-in-adultswho-require-hospitalization diakses tanggal 28 Agustus 2016

Gitawati, R., Interaksi Obat dan Beberapa Implikasinya, Media Litbang Kesehatan, 2009; 18(4): 175-183.

Hussain, F., Arayne, M.S., and Sultana,, Interactions between sparfloxacin and antacids dissolution and adsorption studies. N. Pak. J.Pharm. Sci,2006; 19: (1), 16-21.

Lacy, F.C., Armstrong L, Goldman M.O. Lance L., 2010.Drug Information Handbook: A Clinically Relevant Resource for All Healthcare Professionals,Lexi Comp- Ohio

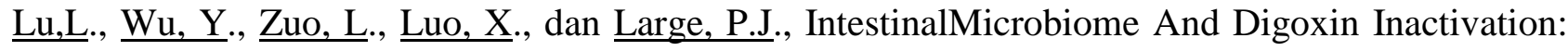
Meal Plan For Digoxin Users?, World J Microbiol Biotechnol, 2014; 30 (3).

Medscape, 2016, Drug Interaction, tersediadihttp://reference.medscape.com/druginteractionchecker, Diakses pada tanggal 3 Mei 2016.

Mega, G.U., Analisis Potensi Interaksi Obat Antidiabetik Oral Pada Pasien Di Instalasi Rawat Jalan Askes Rumah Sakit Dokter Soedarso Pontianak Periode Januari- Maret 2013, JurnalMahasiswa Farmasi Fakultas Kedokteran UNTAN, 2013;3 (1).

Misnadiarly, 2008, Penyakit Infeksi Napas Pneumonia pada Anak, Orang Dewasa, Usia Lanjut, Pneumonia Atipik \& Pneumonia Atypik Mycobacterium, Pustaka Obor Populer, Jakarta.

Prasetya, F., Evaluasi Penggunaan Antibiotika Berdasarkan Kontraindikasi, Efeksamping, Dan Interaksi Obat Pada Pasien Rawat Inap Dengan Infeksi Saluran Pernapasan Bawah Di Rumah Sakit Panti Rapih Yogyakarta Periode Januari-Juni 2005, J. Trop. Pharm. Chem.,2016,1(2): 94-101.

Rizqi M.H., dan Helmia Hasan, Tinjauan Imunologi Pneumonia pada Pasien Geriatri, $\underline{C D K-212}$, 2014;41(1): 14-18. 
Sajinadiyasa. I G K., I M Bagiada, I B Ngurah Rai, Prevalensi Dan Risiko Merokok Terhadap Penyakit Paru Di Poliklinik Paru Rumah Sakit Umum Pusat Sanglah Denpasar, J Peny Dalam; 2010;11 (2): 91-95.

Schelleman, H., Warren, B. B., Colleen M. B., Han, H., Stephen E. K.,dan Hennessy, S., , Warfarin - Fluoroquinolones, Sulfonamides, or Azole Antifungals Interactions and the Risk of Hospitalization for Gastrointestinal Bleeding, Clin Pharmacol Ther,2008; 84 (5):581-588.

Tatro, S.D., 2008, Drug Interaction Facts, Wolters Kluwer Healts, United State of America.

Tjay, T.H., dan Kirana,R., 2007, Obat-Obat Penting Khasiat, Penggunaan dan Efek-Efek Sampingnya, PT. Elex Media Komputindo, Jakarta 